ARTICLE

\title{
Venture Capital in the Rise of Sustainable Investment
}

\author{
Lin $\operatorname{Lin}^{1}$
}

Accepted: 16 December 2021 / Published online: 17 February 2022

(c) T.M.C. Asser Press 2022

\begin{abstract}
In recent years, the world has witnessed a soaring inflow of capital into sustainable investment. This is particularly so following the devastating COVID-19 pandemic. However, while a growing amount of literature has been deliberating debt financing in sustainable investment, less ink has been spilt on equity financing in this area, and even less scholarship has explored the role of government and law in supporting sustainable venture capital ('VC') funds. This paper proposes a dualist approach towards facilitating the development of sustainable VC funds encompassing a contractarian strategy with government support. The contractarian approach includes effective contracting covering the entire VC cycle in sustainable investment. It aims to provide strong incentives for all participants, ranging from investors, entrepreneurs and fund managers, to credit-rating agencies and evaluation firms. In the same vein, this paper seeks to craft a role for regulators that facilitates the simultaneous availability of several factors in a sustainable VC cycle (i.e., fund raising, investment and exit). In the fund-raising stage, governments can play an active role by expanding the source of financing for sustainable VC funds and enacting detailed and targeted legislation. In the VC investment stage, sustainable VC funds should make full use of their strong corporate governance rights and monitoring tasks to ensure that start-ups deliver on their sustainable promises. In the exit stage, a specialised sustainability board is strongly recommended to offer viable exit options, together with greater standardisation and comparability in sustainability information disclosure, and regulatory support for trustworthy sustainable impact rating agencies to sustain investor confidence.
\end{abstract}

Keywords Venture capital $\cdot$ Sustainable investment $\cdot$ Green financing $\cdot$ ESG $\cdot$ Equity investment $\cdot$ VC cycle

Lin Lin

lawll@nus.edu.sg

1 Associate Professor, Faculty of Law, National University of Singapore, Singapore, Singapore 


\section{Introduction}

There has been a surge in the amount of capital flowing into funds practising sustainable investing in recent years, corresponding to heightened investor awareness of issues related to environmental, social and corporate governance ('ESG'). This phenomenon of increasing capital inflow into sustainable investing has occurred both in specific markets, such as the U.S. and Europe, and on a global scale.

The significant increase in the amount of capital flowing into sustainable funds in major markets in recent years is an exciting phenomenon which bodes well for the sector. Unfortunately, while contemporaneous literature on debt financing in green finance is abundant, the same cannot be said about equity financing. ${ }^{1}$ Legal literature is marked by a dearth of coverage concerning green equity financing. Hence, this paper fills a literature lacuna by analysing the roles that VC funds play in sustainable investing, how this works, what the loopholes are and the ways forward from a legal perspective.

Compared to other forms of financing, VC is particularly ideal for sustainable investment given its characteristics. Firstly, VC is uniquely compatible with the needs of sustainable projects. VC funds typically have a long lock-in period, ${ }^{2}$ which aligns well with the need of sustainable start-ups to secure investment for an extended formation period. VC funds are also able to value-add to sustainable startups by providing technical knowledge, industry relationships or management skills, therefore bringing additional benefits to the monetary contribution. ${ }^{3}$ It enables the portfolio company to commercialise cutting-edge science to achieve the innovation needed for sustainable development and accelerates the availability of sustainable solutions, heralding various environmental and social benefits. ${ }^{4}$

Secondly, and more importantly, VC offers strong and unique investor protection mechanisms that are urgently needed in the sustainable investment space given its many uncertainties. VC investment normally comes with strong continuous monitoring and contractual mechanisms to guard against uncertainty and information asymmetry. ${ }^{5}$ For instance, staged financing is often utilised to close information gaps. Knowing that the next round of financing will only be released if key objectives in the business plan are met, entrepreneurs have an incentive to get an accurate valuation of their projects and work hard to attain their goals. ${ }^{6}$ The VC community also runs on an implicit reputation mechanism, where alternative investors would find the project unattractive if existing investors ceased to provide funding in subsequent rounds. VC funds also acquire more control in the portfolio companies and their de

\footnotetext{
${ }^{1}$ For example, see Breen and Campbell (2017), Talbot (2017) or Wang (2018). In comparison, there is scant literature on green equity financing at the time of writing. At best, research on this subject has been conducted in other disciplines such as economics but not necessarily from a legal perspective, see Punzi (2018), Krämer-Eis and Pelly (2011), or Ahmad et al. (2018).

2 Lin (2021), p 10.

3 Ibid., p 2.

4 Bocken (2015).

5 Gilson (2003), p 1078.

${ }^{6}$ Ibid., pp 1078-1081.
} 
facto influence over decision-making is often disproportionately larger than the voting rights associated with their equity holdings. ${ }^{7}$ Accordingly, VC fund managers often become directly involved in the corporate governance of portfolio companies and steer them towards sustainability. This also provides an extra incentive for entrepreneurs to properly manage their companies in order to regain their control rights. There are also other contractual mechanisms designed for investor protection, such as drag along rights, tag along rights, and right of first refusal. ${ }^{8}$

Against this backdrop, this paper proposes a contractarian strategy in facilitating the development of sustainable $\mathrm{VC}$ funds and seeks to craft a role for government that promotes the simultaneous availability of several factors in a sustainable VC fund cycle (fund raising, investment and exit). The contractarian approach includes effective contracting covering the entire VC cycle in sustainable investment. It aims to provide strong incentives for all participants, ranging from investors, entrepreneurs and fund managers, to credit-rating agencies and evaluation firms. The twopronged approach suggested here would address the need to mobilise entrepreneurship, innovation as well as private sector funding capacity to support the growth of the sustainable VC market. The proposed strategy involves the following 3 stages:

(1) At the fund-raising stage, sustainable VC funds could adopt a different approach when negotiating with investors as compared to previously rigid standard practice. Furthermore, governments can play an active role by expanding the source of financing for sustainable $\mathrm{VC}$ funds through relaxed regulations for institutional investors, the provision of a clear and authoritative definition of sustainable investment and the consolidation of sustainable standards. Concurrently, stakeholders may consolidate sustainable standards. Ultimately, these would craft a role for the government that facilitates the VC market premised on private contracting rather than on heavy government intervention in the capital allocation decision.

(2) During the VC investment stage, greater comparability in sustainability information disclosure by green projects is required. This would need to be supervised and enforced.

(3) In the exit stage, educating investors to pique their interest in green portfolio companies and broadening exit options is crucial for the successful exit of sustainable VC funds. Junior markets or flexible listing rules may be introduced for sustainable start-ups and this could be supported with enhanced disclosure measures. In sum, the suggestions made in this paper could be valuable to countries or regions that are attempting to promote the formation and growth of sustainable investments through equity financing.

This paper proceeds as follows. Section 2 gives an overview of venture capital in the rise of sustainable investment and several similar concepts relating to sustainable investment. Section 3 discusses the different kinds of sustainable fund structures,

\footnotetext{
7 Ibid., p 1082.

${ }^{8}$ Lin (2021), pp 163-175.
} 
backed by examples. Subsequently, Section 4 provides detailed recommendations to improve the legal and regulatory framework for VC green investment commensurate to the problems identified, spanning the fund-raising, investment and exit stages. Section 5 concludes.

\section{Venture Capital in the Rise of Sustainable Investment}

According to the 2020 Global Sustainable Investment Review, a biannual report published by the Global Sustainable Investment Alliance (GSIA), ${ }^{9}$ the total sustainable investing assets in the five major global markets studied (Europe, U.S., Canada, Japan and Australasia) ${ }^{10}$ stood at USD\$ 35.3 trillion at the start of 2020, a 55\% jump from four years earlier in 2016. At the start of 2020, sustainable investing assets already commanded a sizeable share of $35.9 \%$ of professionally managed assets in these five major markets. ${ }^{11}$

Figure 1 below represents the growth in total sustainable investing assets in the five major markets studied in the GSIA's biannual reports from 2012 to 2020. A clear upward trend can be observed in terms of both the total amount of sustainable investing assets and their share of the total professionally managed assets.

It is reasonable to infer that the size of total sustainable investing assets on a global scale is larger than the value reported by the above GSIA Review, since there are many other sustainable investment markets in developing countries such as China and India that are not covered by the Review. Regrettably, statistics are often incomplete in those countries. For example, in China, the amount of publicly held ESG funds alone is reported to be RMB 48.6 trillion (USD\$ 7.55 trillion), whereas there is no complete set of data on private funds at national level. ${ }^{12}$

At the outset, there are a few similar concepts that need to be discussed and distinguished. These concepts include sustainable investing, socially responsible investing, ESG investing, impact investing and green finance. Figure 2 below presents a chart illustrating the definitions and relationship of these concepts.

In this paper, the term 'sustainable investing' is used as an overarching concept that covers socially responsible investing, ESG investing and impact investing. This term is chosen for its deliberately broad and inclusive scope, and corresponds well with the actual practices of VC funds which, except for very specialised funds, by and large do not make minute distinctions between these concepts and often lump them under the title of sustainable investment.

\footnotetext{
9 The Global Sustainable Investment Alliance (GSIA) is an international collaboration of membershipbased sustainable investment organisations, including the European Sustainable Investment Forum (Eurosif), US SIF, Responsible Investment Association Canada, Responsible Investment Association Australasia and Japan Sustainable Investment Forum.

10 Global Sustainable Investment Alliance (2021).

11 Ibid.

12 China Social Investment Forum (2019).
} 
Fig. 1 Growth of global sustainable investing assets from 2012 to 2020 (The Figure has been drawn by the author based on data from Global Sustainable Investment Alliance (2013), Global Sustainable Investment Alliance (2015), Global Sustainable Investment Alliance (2017), Global Sustainable Investment Alliance (2019) and Global Sustainable Investment Alliance (2021))

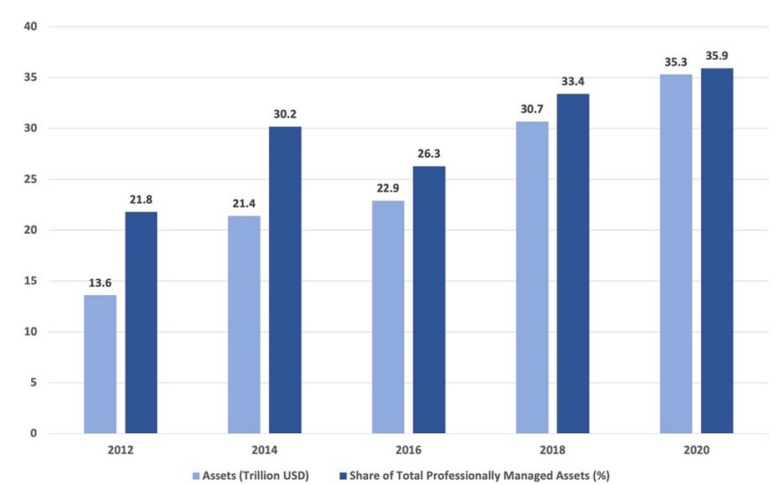

The GSIA defines sustainable investing as 'an investment approach that considers environmental, social and governance (ESG) factors in portfolio selection and management ${ }^{13}$. Similarly, BlackRock recognises that sustainable investing is achieved through a combination of traditional investment approaches with ESG insights. ${ }^{14}$ Furthermore, the Sustainable Funds U.S. Landscape Report published by Morningstar broadly places sustainable funds in three categories: (1) ESG Focus, (2) Impact/ Thematic, and (3) Sustainable Sector. ${ }^{15}$

According to the EU Sustainable Investment Taxonomy Regulation of 18 June $2020,{ }^{16}$ 'environmentally sustainable investment' means an investment in economic activities that qualify as 'environmentally sustainable' under the Regulation. ${ }^{17}$ The criteria for qualifying as an environmentally sustainable economic activity include: ${ }^{18}$ (1) substantial contribution to one or more of the environmental objectives $;^{19}$ (2) absence of significant harm to one or more of the environmental objectives $;^{20}$ (3)

\footnotetext{
${ }^{13}$ Global Sustainable Investment Alliance (2019), p 7 [emphasis added].

${ }^{14}$ BlackRock (undated a).

${ }^{15}$ Hale (2020). ESG Focus refers to funds that intentionally make ESG factors a central consideration in portfolio selection and construction, while Impact/Thematic refers to funds that seek to create a positive impact alongside financial returns. The third category, Sustainable Sector, refers to funds that invest in 'green economy' industries such as renewable energy and environmental protection. Noticeably, funds that merely mention ESG considerations in their analysis but omit details on how these ESG considerations are central or material to their portfolio selection and construction are excluded from the Landscape Report's definition of sustainable funds.

${ }^{16}$ European Union, Regulation (EU) 2020/852 of the European Parliament and of the Council of 18 June 2020 on the establishment of a framework to facilitate sustainable investment, and amending Regulation (EU) 2019/2088.

${ }^{17}$ EU Sustainable Investment Taxonomy Regulation, Article 2(1), definition of 'environmentally sustainable investment'.

${ }^{18}$ Ibid., Article 3: Criteria for environmentally sustainable economic activities.

19 Ibid., Article 9 sets out the environmental objectives, i.e., climate change mitigation and adaptation, the sustainable use and protection of water and marine resources, the transition to a circular economy, pollution prevention and control, and the protection and restoration of biodiversity and ecosystems.

${ }^{20}$ Ibid., Article 17 provides the definition of significant harm to environmental objectives, including significant greenhouse gas emissions, and an increased adverse impact of the current climate and the expected future climate, among others.
} 


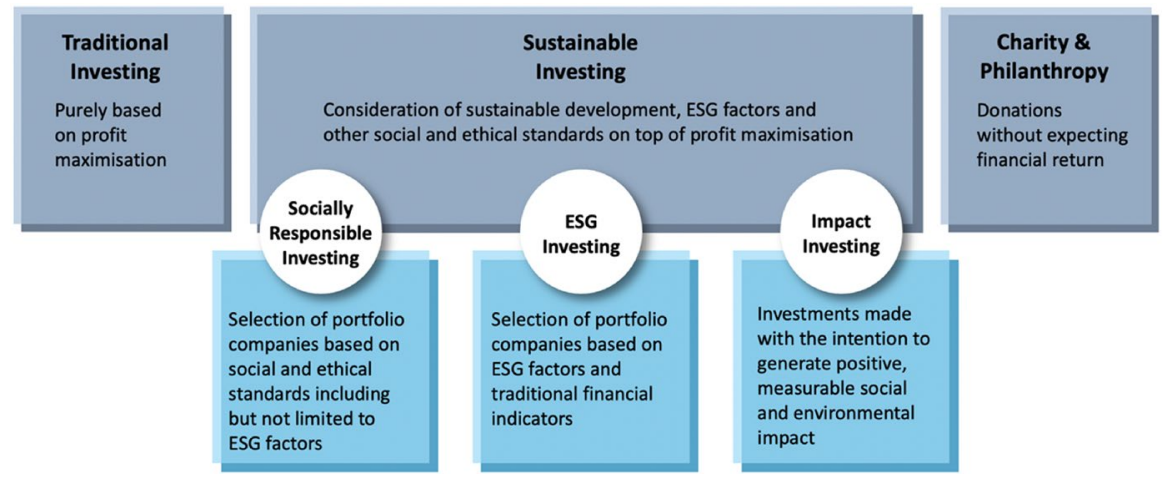

Fig. 2 Definition of concepts related to sustainable investing (For the sources of the definitions of these closely associated concepts, see the text accompanying notes 13 to 30 )

compliance with the minimum safeguards, ${ }^{21}$ and (4) compliance with technical screening criteria. ${ }^{22}$

In this regard, some closely related concepts are defined in ways largely similar to sustainable investing. For instance, the UN Principles for Responsible Investment (PRI) set out a voluntary and aspirational set of six investment principles that enable the incorporation of ESG issues into investment practice. ${ }^{23}$ The six principles include, inter alia: (1) incorporation of ESG issues into investment analysis and decision-making; (2) active ownership and incorporation of ESG issues into ownership policies and practices; and (3) appropriate disclosure on ESG issues by portfolio companies. ${ }^{24}$

As for impact investing, the Global Impact Investing Network defines it as 'investments made with the intention to generate positive, measurable social and environmental impact alongside a financial return', addressing urgent issues such as sustainable agriculture and renewable energy. ${ }^{25}$ It can target both developing and developed markets, with a rate of return equal to or lower than market rate. ${ }^{26}$ It should also be noted that some studies tend to categorise impact investing as a strategy of sustainable investing, together with other strategies such as negative screening and ESG integration. $^{27}$

\footnotetext{
${ }^{21}$ Ibid., Article 18 sets out the minimum safeguards, most importantly in terms of compliance with the OECD Guidelines for Multinational Enterprises and the UN Guiding Principles on Business and Human Rights, including the principles and rights set out in the eight fundamental conventions identified in the Declaration of the International Labour Organisation on Fundamental Principles and Rights at Work, and the International Bill of Human Rights.

${ }^{22}$ Ibid., Articles 10(3), 11(3), 12(2), 13(2), 14(2) and 15(2) set out the technical screening criteria.

${ }^{23}$ UN Principles for Responsible Investment (2021). See also for a similar definition of responsible investing AXA Investment Managers (2021) and Fidelity International (2021).

${ }^{24}$ UN Principles for Responsible Investment (2021).

${ }^{25}$ Global Impact Investing Network (2021).

${ }^{26}$ Ibid.

${ }^{27}$ See, for example, Global Sustainable Investment Alliance (2019), p 9.
} 
Green finance broadly refers to efforts by the financial community to mitigate the global environmental challenge, while bearing in mind risk-return priorities as usual. ${ }^{28}$ More precisely, the definition of green finance requires clarification of two separate aspects: first, of sectors or activities that can be financed by green funds, including but not limited to contributions to climate change mitigation and adaptation; and second, of the specific operational standards that must be followed before certain financial products can be considered green finance. ${ }^{29}$

Figure 2 above summarises the definitions of overlapping terms canvassed above, and is modified from a conceptual mind map developed by the China Alliance of Social Value Investment. ${ }^{30}$

\section{Evolving Sustainably Focused Funds}

There exists a broad array of different types of funds that make sustainable investments. There are market-oriented private funds, public-private collaboration funds, and public funds based on their sources of funding. This Section examines the differences in terms of sources of funding, organisational structure, portfolio selection and construction, and exit strategies between these various types of sustainable funds. These key differences are summarised in Figure 3 below, and further explained in the subsequent description.

\subsection{Market-oriented Private Fund}

\subsubsection{Basic Characteristics}

Similar to conventional VC funds, market-oriented sustainable VC funds ${ }^{31}$ source their committed capital from accredited investors and institutional investors. ${ }^{32} \mathrm{~A}$ typical structure of such a fund based on a limited partnership is provided in Fig. 4. In order to materialise the returns of their investments in portfolio companies, their exit strategies generally involve listing the portfolio companies via IPOs, or Mergers \& Acquisitions (M\&A) by larger corporations. ${ }^{33}$ In terms of selection and construction of portfolio companies, they use ESG integration while adopting other

\footnotetext{
${ }^{28}$ Berrou et al. (2019), pp 3-4.

29 Ibid., pp 31-32.

30 Zhang and Lu (2020).

31 It should be noted that there is a growing trend amongst broader private equity (PE) and VC funds to integrate ESG factors and considerations into their investment policies. Some examples include KKR and Blackstone. However, for reasons of prudence, the focus of this paper remains centred on VC funds.

32 Lin (2019), pp 563-594. See further, e.g., my interview with Ms Lv from Impact Hub Shanghai, 29 Oct 2020 (script with author), in which she mentioned that a bulk part of their LPs included sophisticated investors from wealthy families.

33 An et al. (2018), p 24. See further, e.g., my interview with Mr Cui Fang from UOB Venture Management, 29 Oct 2020 (script with author), and my interview with Mr Bai Bo, CEO from Asia Green Fund, 28 Oct 2020 (script with author), in which they both mentioned that the exit strategies are similar to those of conventional VC funds and primarily included IPOs and M\&As.
} 
traditional selection methods. ${ }^{34}$ Market-oriented private sustainable funds are generally established in either of two ways: (1) by creating a new fund specifically catered to sustainable investing; or (2) by expanding an existing fund into the sustainable sector. Examples of these two approaches are provided in the following sub-sections.

\subsubsection{New Fund vs Expanding an Existing Fund}

Setting up a new fund specially catered to sustainable investing helps to signal the fund's commitment to and speciality in sustainable investing as a unique point of attraction for conscientious investors. ${ }^{35}$ Many of these funds display their exclusive commitment to sustainable investing on the frontpage of their website. For instance, SET Ventures is the only fund in Europe that is $100 \%$ focused on transitioning the carbon-intense energy system to a robust sustainable energy system. ${ }^{36}$ Similarly, ETF Partners - the Environmental Technologies Fund-invests in early-stage European companies that deliver sustainability through innovation. ${ }^{37}$ U.S. examples include DBL Partners, which imposes a 'double bottom line' of top tier VC financial returns and positive ESG impacts in its portfolio selection, ${ }^{38}$ and Social Impact Capital. ${ }^{39}$ In China, such examples are also emerging, e.g., Green Leaves Investment, the first Chinese fund that invests in early-stage green start-ups, ${ }^{40}$ and Tsing Capital. ${ }^{41}$

Alternatively, instead of setting up a new fund, many established funds simply expand a portion of their portfolio selection so as to incorporate sustainable investing concepts. BlackRock, for instance, has specifically created a 'sustainable investing' category among its investment strategies. ${ }^{42}$ It offers its clients a spectrum of sustainable investing styles, from 'avoiding' portfolio companies with negative ESG characteristics to 'advancing' portfolio companies with positive ESG characteristics. ${ }^{43}$ ESG integration is also made possible with a strategy that involves actively implementing ESG-friendly approaches in the process of selecting and developing portfolio companies. ${ }^{44}$ Other major funds have followed this trend as reports have shown that $11 \%$ of VC firms in the U.S. now invest through an ESG lens. ${ }^{45}$

\footnotetext{
34 Global Sustainable Investment Alliance (2019), p 9.

35 Examples of such funds can be found in major markets around the world. In Europe, general partners (GPs) of successful sustainable VC funds are invited to speak at the EcoSummit Conferences held on a monthly basis. See EcoSummit (undated). See their past events' speakers list for an almost comprehensive collection of sustainable VC funds in Europe.

36 SET Ventures (undated). By investing in energy transition, it also fulfils the UN Sustainable Development Goals (SDG) of affordable and clean energy (SDG 7) and industry, innovation and infrastructure (SDG 9).

37 ETF Partners (undated).

38 DBL Partners (undated).

39 Social Impact Capital (undated).

40 Green Startups (undated).

41 Tsing Capital (undated).

42 BlackRock (undated a).

43 BlackRock (undated b).

44 BlackRock (undated c).

45 Different Funds (2020).
} 


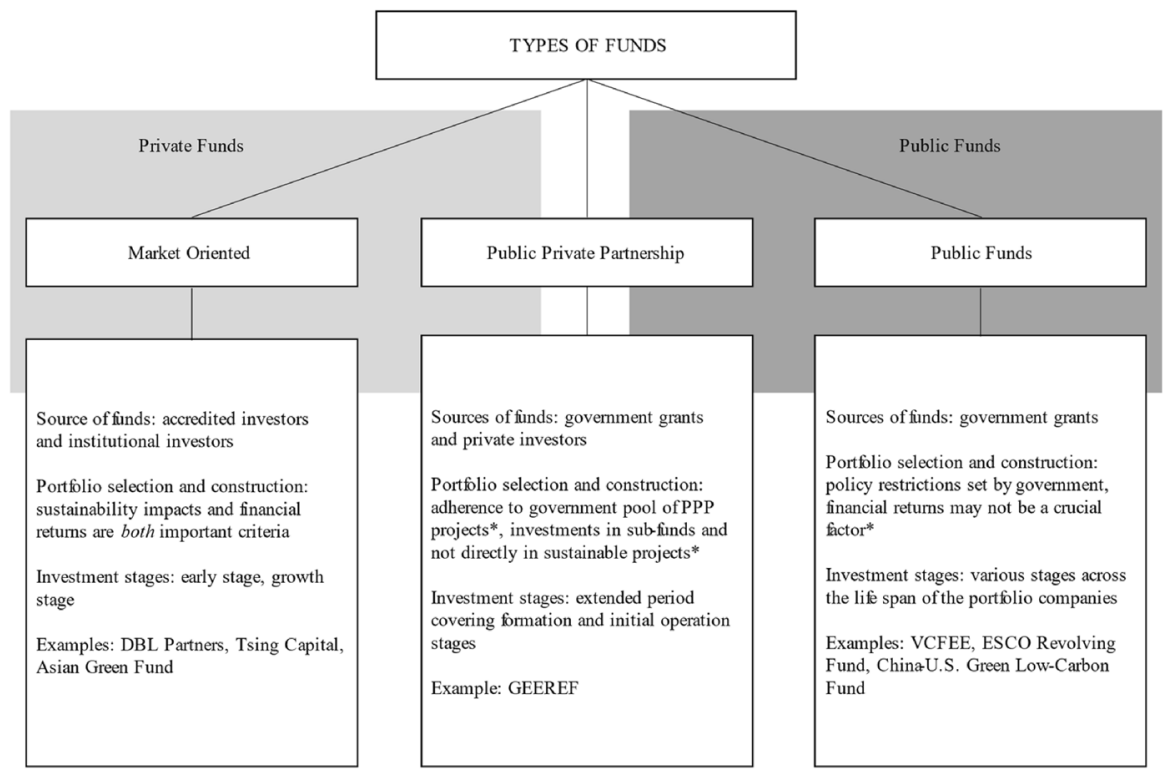

Fig. 3 Types of sustainable funds and characteristics (See for a more detailed explanation and citation of sources the following text accompanying notes 31 to 83 . While only short forms of the funds are provided in this Table, their full names can be found in the following text. Asterisks $(*)$ indicate optional features)

Fig. 4 Structure for limited partnership—type sustainable VC funds

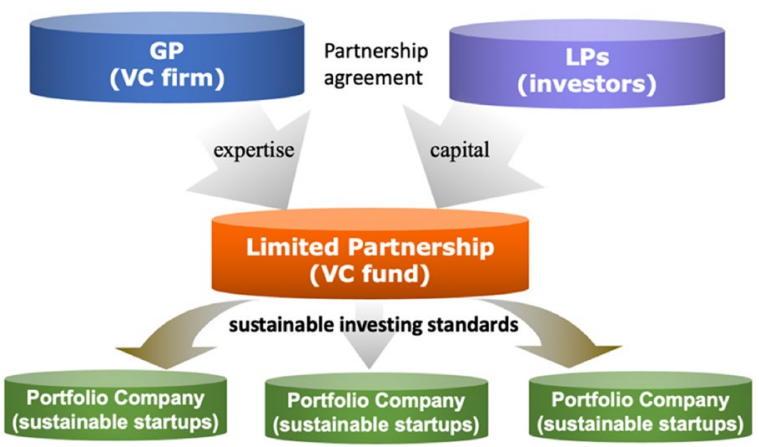

\subsection{Public-Private Partnership}

\subsubsection{Basic Characteristics}

A Public-Private Partnership (PPP) is designed for situations where government funds or private funds are themselves insufficient or restricted in providing financing to massive infrastructure projects with a sustainable focus (e.g., transport, energy, healthcare). A PPP normally involves collaboration between state organs and private funds through the pooling of funds, management and collective decision-making in 
terms of portfolio selection and construction. ${ }^{46}$ Compared to private market-oriented funds, a PPP has numerous advantages including, among others, stronger credibility due to government support, a longer investment period covering the extended formation and initial operation stages, and a larger pool of private and government resources and networks. ${ }^{47}$

However, one must also be cognisant of the potential drawbacks of the PPP model. As observed in Canada, the PPP model has resulted in issues such as crowding out, and overcharging for underperformance. Canadian Labour-Sponsored Venture Capital Corporations (LSVCCs) have even been criticised for reducing the amount of venture capital supply in Canada. As a result, this hindered the maturation of the Canadian VC industry and 'set [it] back ... by many years'. ${ }^{48}$ At the same time, the selection of portfolio companies by PPPs is often limited by policy considerations stipulated by the government, curtailing the free reign of the fund managers. ${ }^{49}$ For example, the selection of portfolio companies by the China Public-Private Partnership Investment Fund Co., Ltd (China PPP Fund) requires some form of recognition by the government in its PPP Project Databases. ${ }^{50}$ Therefore, it may appear ostensibly true that underperformance as observed by Cumming et al.'s research (in the Canadian context) may materialise. Nevertheless, this may not necessarily be true for sustainability-oriented VC and it remains an open question as to whether such sustainable PPP models have the propensity to tend towards underperformance. $^{51}$

A typical PPP may follow either of the following three structures. ${ }^{52}$ First, it could be a stand-alone fund where the investment is pooled from state organs, financial institutions and other investors. ${ }^{53}$ Second, it could be a fund of funds (FoF) where the sub-funds receive investment not only from the parent fund but also from other sources of investment, similarly consisting of state organs, financial institutions and other investors. ${ }^{54}$ The second structure is the most useful when the central or federal government controls and invests in the parent fund while local or provincial governments control and invest in the sub-funds specifically designed for each local area. Third, it could adopt a FoF structure where the sub-funds only receive investment from the parent fund.

\footnotetext{
46 An et al. (2018), p 79.

47 Ibid., pp 82-83.

48 Cumming et al. (2017).

49 Ibid.

${ }^{50}$ China PPP Fund (2016). The exact requirements are (1) listing by the Ministry of Finance in its Comprehensive Information Platform PPP Project Management Database, or by the China Development and Reform Commission in its PPP Project Database, and/or (2) inclusion in the special plans for national economic and social development, infrastructure and public services, or otherwise determined as major projects by the State Council.

51 Cumming et al. (2017).

52 An et al. (2018), pp 85-87.

53 See, for instance, the European Investment Fund 2/3rd of which consists of private money on top of state funds.

54 Nassiry and Wheeler (2011), p 4.
} 


\subsubsection{Prominent Examples}

One prominent example of a PPP fund is the China PPP Fund, whose 11 shareholders include the Ministry of Finance, the National Social Security Fund, the People's Bank of China, and other financial institutions. ${ }^{55}$ The China PPP Fund was established in March 2016 with the endorsement of the State Council, while its management company, the China PPP Fund Management Co., Ltd, was set up shortly after, in July 2016. As of 31 December 2019, the China PPP Fund manages a total investment of RMB 1.3 trillion (USD $\$ 203$ billion) in 155 projects, and supports infrastructure development, environmental protection and public service projects in 28 provinces. ${ }^{56}$ An outstanding example of an international PPP fund is the ChinaU.S. Green Fund. First conceived in 2015, when China's President Xi Jinping visited the United States, and formally registered in 2017, the China-U.S. Green Fund is a joint creation of the governments and business communities in China and the U.S. ${ }^{57}$ Its first round of $\mathrm{VC}$ investment amounted to more than two billion RMB, and soon after exceeded three billion RMB in $2018 .{ }^{58}$

The China-U.S, Green Fund uniquely adopts the P.R.I.M.E model: Policy, Research, Integration, Money and Execution. ${ }^{59}$ This model effectively means that under the guidance and facilitation of government policies, the fund is executed by professional management teams, who have integrated money, technology and commercial considerations in managing the portfolio ${ }^{60}$ In terms of operations, the fund adopts a purely market-oriented approach, as strongly encouraged by the Guiding Opinions on Building a Green Financial System issued in 2016. ${ }^{61}$ Adopting a purely market-oriented approach means that the fund relies entirely on its professional management teams to generate positive returns and cannot rely on government subsidies to cover losses. Furthermore, the China-U.S. Green Fund has set up a Green Fund Research Centre for the purpose of evaluating the ESG impact of portfolio companies. ${ }^{62}$ Successful portfolio companies managed by the fund include the Horen Group, which developed a recyclable industrial packing system based on the internet of things, and AIpark, which provides AI-based unmanned management of urban parking lots. ${ }^{63}$ The China-U.S. Green Fund also has a FoF structure and has a number of high-profile sub-funds, such as the Four Rivers Investment Management Company. ${ }^{64}$ This company in turn owns China's first steel industry structure adjustment fund aimed at achieving greater energy efficiency and cleanliness in the

\footnotetext{
55 China PPP Fund (2016). Such other financial institutions include, for example, the China Construction Bank and China International Trust and Investment Corporation.

56 China Public Private Partnership Centre (2020).

57 An et al. (2018), pp 221-222.

$58 \mathrm{Lu}$ (2018).

59 China-U.S. Green Fund (2021).

60 An et al. (2018), pp 224-231.

61 People's Bank of China (2016), §4.19.

62 Sohu (2020). The author notes that the China-U.S. Green Fund is managed by the Asian Green Fund.

63 Asia Green Fund (undated).

64 Four Rivers Investment (undated).
} 
steel industry. ${ }^{65}$ Another example is the Three Gorges Green Fund, which focuses on investing in clean energy, environmental protection and a green production line. ${ }^{66}$

The PPP structure can be found in major markets such as the U.S. and the EU as well. For instance, the Global Energy Efficiency and Renewable Energy Fund (GEEREF), initiated by the European Commission and advised by the European Investment Bank Group, adopts a PPP and FoF structure by leveraging public sector funds to invest in specialist renewable energy and energy efficiency private equity funds in emerging markets. ${ }^{67}$ As a PPP, the GEEREF is able to obtain funding from both the public and private sector, having received a $€ 112$ million contribution from the European Union, and the German and Norwegian governments in 2008, and another $€ 112$ million from private investors in $2015 .^{68}$ Adhering to a triple bottom line of people, planet and profit, GEEREF invests in 79 developing countries across Africa, Central and South America, as well as South-East Asia. ${ }^{69}$ In a similar vein, the European Investment Fund (EIF), an EU-sponsored development fund, will only invest if sustainability criteria are taken into account, even though the EIF is not a 'sustainable only' fund. Furthermore, it should be observed that most, if not all, EU vehicles do adhere to such similar sustainability criteria further to the EU Sustainable Finance Action Plan 2018. ${ }^{70}$ A U.S. example is P4G-Pioneering Green Partnerships, Investing in Impact-which is headquartered in Washington D.C. and collaborates with government ministries in a number of countries to promote five of the UN SDGs. ${ }^{71}$

Lastly, no discussion would be complete without mention of certain forms of matching funds. Such matching funds facilitate the matching of public and private capital in a particular sustainable investment in accordance with a defined ratio. Some notable examples include France's Ecotechnologies Fund and Argentina's Fiduciary Fund for the Development of Venture Capital (FONDCE). ${ }^{72}$

\subsection{Public Fund}

\subsubsection{Basic Characteristics}

In order to overcome the difficulties in obtaining private financing for sustainable projects, a number of governments and international organisations have set up public funds to support such projects. Most of these public funds are conceptually broader than a typical VC fund, as they invest across different stages of the life span of the portfolio companies and utilise an array of investment tools covering equity

\footnotetext{
65 Xinhua News Agency (2017).

66 Sina Finance (2020).

67 GEEREF (2021a).

68 GEEREF (2021b).

69 GEEREF (2021c).

70 Communication from the Commission to the European Parliament, the European Council, the Council, the European Central Bank, the European Economic and Social Committee and the Committee of the Regions. Action Plan: Financing Sustainable Growth, COM/2018/097 final.

71 Zabarenko et al. (2018), pp 3 and 28.

72 Ahmad et al. (2018), p 25.
} 
investment, debt investment or even a combination of both. ${ }^{73}$ Nevertheless, a number of these public funds are exclusively focused on the VC stage of investment, and some examples are cited in the following sub-section. Unlike market-oriented private funds or PPP funds, public funds tend to rely heavily or exclusively on government grants or subsidies. ${ }^{74}$ Sometimes, there are also stricter limitations on the type of projects that can be funded. ${ }^{75}$

\subsubsection{Prominent Examples}

Examples of public funds set up by the government for the purpose of sustainable development can be found in numerous countries around the world. For instance, the Venture Capital Fund for Energy Efficiency (VCFEE) was set up by the Indian Bureau of Energy Efficiency in $2017 .^{76}$ It provides last-mile equity support to selected energy efficiency projects, limited to $15 \%$ of total equity required by the projects. ${ }^{77}$ It is noteworthy to point out that in the first phase of the VCFEE, investments can only be made in government buildings and in energy efficiency projects supported by municipalities. ${ }^{78}$ In Thailand, the ESCO Revolving Fund was established in 2008 and has undergone four phases so far. ${ }^{79}$ It aims to encourage private investments in renewable energy and energy efficiency projects. The arsenal of financial services offered by the fund include equity investment, venture capital and equipment leasing. ${ }^{80}$

In China, it has gradually become a trend for provincial governments to set up green development funds and environmental protection funds. ${ }^{81}$ In particular, as a joint initiative between the Beijing Environment Exchange and the China-U.S. Green Fund, the China-U.S. Green Low-Carbon Fund was set up in the Xiong'an New Area in $2017 .{ }^{82}$ With the estimated size of the fund exceeding RMB 10 billion (USD\$ 1.5 billion), it seeks to boost liquidity in China's national carbon emission trading market, and assists green development funds in the quantification, collection and commercialisation of carbon assets. ${ }^{83}$ Additionally, the fund also invests in domestic and overseas projects with a focus on low-carbon energy efficiency, green smart cities and green villages.

\footnotetext{
73 An et al. (2018), pp 41-44.

74 Ibid., p 223. See also the explanation of the examples cited below.

75 See, for example, text accompanying notes 76 to 78, stating that the VCFEE fund in India is limited to only investing in 'government building or municipality projects'.

76 Bureau of Energy Efficiency (undated a \& b).

77 An et al. (2018), at p 2.

78 An et al. (2018).

79 Energy for Environment Foundation (2021).

80 Ibid.

81 An (2017), p 73.

82 Beijing Daily (2017).

83 Ibid.
} 


\section{Legal and Regulatory Needs for Mobilising Sustainable VC}

The unique advantages of VC funds in financing sustainable projects, in terms of fulfilling the needs of green start-ups and offering distinctive investor protection mechanisms, have been canvassed in Section 2 above. Nevertheless, despite these advantages and a soaring interest from investors in sustainable investing in recent years, particularly in the midst of the COVID-19 pandemic, there remains a significant amount of apprehension in this relatively new and underdeveloped area which deters investors from actually committing their capital. ${ }^{84}$ Apart from the conventional contracting problems in financing start-ups (i.e., uncertainty, information asymmetry) and the familiar agency problems, parties involved in sustainable VC funds face a set of specific problems. In general, such challenges can be summarised as how to incubate and maintain investor interest and confidence through contractual and regulatory means, how to ensure that portfolio companies stay true to and deliver on their sustainable promises, and how to construct credible mechanisms to verify the environmental impact of sustainable projects. This article examines the specific challenges in each stage of sustainable VC funds and makes recommendations to address these challenges.

\subsection{Fund-raising Stage}

There remains a multitude of problems experienced by sustainable VC funds during the fund-raising stage. These can pertain to the perception of investors towards sustainable VC funds, a mismatch in maturity between sustainable and traditional VC funds, and the lack of norms, laws or regulations necessary to internalise environmental externalities and to provide a uniform approach and uniform sustainability standards for sustainable VC funds.

In relation to sustainable $\mathrm{VC}$ funds, there exists a perception that sustainable green VC funds have a less attractive risk-to-return profile as compared to other, traditional VC funds. This is due to 'long holding periods, illiquidity, additional investment restrictions, and limited exit prospects' or even additional costs that might be incurred to comply with any prevailing sustainability requirements. ${ }^{85}$ These factors make sustainable VC funds a 'less commercially attractive [proposition]' ${ }^{86}$ as compared to traditional VC funds. In furtherance of this comparison with traditional VC funds, this perception may be further exacerbated by a 'maturity mismatch' where most traditional VC funds operate in more developed capital markets and invest in companies with more familiar growth cycles or investment horizons as compared to sustainable VC funds. ${ }^{87}$ Investors may also be deterred by the new attendant risks that come with investing in 'nascent industries' such as whether such technology could indeed prove effective, and even if it is effective, whether it will be scalable. ${ }^{88}$

\footnotetext{
${ }_{84}$ Standard Chartered PLC (2020), p 10.

85 Ahmad et al. (2018), p 40.

86 Ahmad et al. (2018).

87 Ibid.

${ }^{88}$ Ibid., p 41.
} 
The future of such industries with technology in its infancy is often clouded with uncertainty, which may compromise their commercial viability. Ostensibly, these considerations could possibly weigh down on investors' minds, thus contributing towards their hesitancy towards sustainable VC funds.

There is also a lack of knowledge regarding the norms of sustainable investing, including ESG risk management standards and practices. Financial intermediaries also have inadequate instruments and incentives to price and internalise environmental externalities which reduce 'the financial returns of sustainable projects' ${ }^{89}$ Such inability to internalise these externalities may be attributable in part to the lack of a 'carbon market' or to 'inadequate laws and regulations penalising pollution and emission, ${ }^{90}$ or even to the sheer lack of sustainability standards and data for screening sustainable projects or assets.

At present, sustainable finance is shrouded by a general state of ignorance engendered by a 'lack of data on [the] profitability of sustainable investments', a lack of 'broadly acknowledged theoretical insights ... into the co-relation and causation of sustainability factors with financial data' which 'hinder ... a rational, calculated approach to allocating funds with a view to sustainability' which is normally associated with "finance'. ${ }^{91}$ This lack of data which leads to the inability to come to a consensus on an agreed standard has consequently stemmed the flow of 'public and private capital' to 'finance sustainable growth'. ${ }^{92}$

As a result, there currently remains a lack of a clear, authoritative and consistent definition and conception of 'sustainability framework' in many countries, even though a broad consensus regarding a generic idea has emerged. ${ }^{93}$ This is yet another problem that plagues the fund-raising stage of sustainable VC funds. The European Sustainable Funds Report issued by Morningstar in 2019 observed that as both conventional and sustainable funds have increased the usage of ESG language in their prospectuses, the description of ESG contributions in their legal and marketing documents is often ambiguous, incomplete and unstandardised.$^{94}$ Investors may also be interested to find out exactly under which of the ESG limbs the company falls. Equally importantly, a set of benchmark standards should be created for investors to appreciate the different extent to which funds and companies commit themselves to sustainability issues.

While the present practice is that some more established funds have created their own research centres and ESG assessment guidelines, ${ }^{95}$ these measures are limited in their applications as funds tend to devise divergent standards that best suit their own investment objectives. Also, not every VC firm has such resources or capacity to set up an internal research centre to conduct sustainable due diligence of portfolio

\footnotetext{
${ }^{89}$ Ibid., p 40.

90 Ibid., p 40.

91 Zetzsche (2021).

92 Ahmad et al. (2018), p 40.

93 Bioy et al. (2019).

94 Ibid., pp 21-22.

95 For example, the China-U.S. Green Fund set up its own Green Fund Research Centre, see text accompanying note 62. In my interview with Mr Cui Fang from UOB Venture Management, 29 Oct 2020 (script with author), he mentioned that UOB engages with third-party service providers to conduct ESG due diligence.
} 
companies. Further, it is costly and less efficient for VC firms to outsource such work to third-party specialists, such as sustainability credit-rating agencies, whose role is explained in the next Section. In this research centre scenario, the problems of asymmetric information and agency costs are hidden between the investors and the sustainability research centre run by the funds. ${ }^{96}$ Driven by the interest to attract more sustainability-friendly investors and to highlight the impact of their sustainable investment, fund managers may be incentivised to paint a rosier picture of what their portfolio companies achieved than is actually the case. Potential investors would hesitate to invest without a clear sign of certainty and recognition, hindering fund raising for sustainable $\mathrm{VC}$ funds. ${ }^{97}$

Hence, it is imperative that these issues which pose an obstacle to fund raising for sustainable VC funds be addressed. This paper thus provides some recommendations to address the aforementioned concerns. To be fair, it would be difficult to change an investor's perception towards fund raising for sustainable funds. Even if one were to argue for some form of educational effort, its ostensible impact would be difficult to measure and evaluate. Therefore, changing an investor's perception is a long-term endeavour. Hence, a more appropriate approach would be to prioritise the other issues that sustainable VC funds face during fund raising-not only are these issues more pertinent, but solving them would arguably have positive implications for investor perception as well for boosting investor confidence. These issues are the maturity mismatch and attendant risks that come with investing in a nascent industry, the lack of norms, laws or regulations necessary to internalise environmental externalities, and the lack of data for constructing applicable uniform standards linking sustainability and finance.

This paper's recommendation can be understood in two ways, based on the entity which takes the requisite action: either the sustainable VC fund itself, or the government of the country where the fund is domiciled.

As regards sustainable VC funds themselves, it is suggested that they may look towards adapting their approach to the sustainable investing sector so as to better attract capital in the fund-raising process through amending previously strict contractual terms ${ }^{98}$ between themselves and their investors. A similar approach was proposed by Lerner, albeit in the context of venture capital in financing innovation. ${ }^{99}$ Notwithstanding this contextual difference, his observations remain compelling and it is submitted that a similar approach may be adopted in the fund-raising process for sustainable VC funds. Indeed, Lerner himself alludes to the innovative industries including renewable energy technology, ${ }^{100}$ which would more likely than not be

\footnotetext{
96 Christie (2021).

97 As a matter of last resort, sustainable VC funds could also rely on contractual mechanisms such as representations and warranties, and indemnifications to guard against the negative repercussions arising from poor-quality, or even fraudulent, disclosures.

${ }^{98}$ Such as terms mandating the lifetime of the fund in which case the fund would seek to exit from its investment, or the potential degree of involvement that the VC fund would have in the portfolio company. With a more suitable exit timeframe tailored to the specific sector, as well as the reassurance that investors may get from knowing that fund managers would be active investors instead of being overly passive, this may have a confidence-boosting effect advancing the fund-raising process.

99 Lerner and Nanda (2020).

100 Ibid., p 248.
} 
considered as a form of sustainable finance and in this context could possibly be the scope of applicability for sustainable VC funds.

This contractual approach would also address the maturity mismatch raised by the IFC Report. ${ }^{101}$ Appropriate contractual amendments and tweaks can be made between the sustainable VC fund and the investors to address the attendant risks found in investing in such nascent industries, and variation in the maturity period for sustainable VC funds may be included to cover funds which require this, such as funds with different investment foci in a myriad of sustainable sectors. ${ }^{102}$ This is a good opportunity to 'rethink' VC partnerships as Lerner suggests, ${ }^{103}$ and sustainable VC funds may be just the appropriate candidates to kickstart the process.

Separately, respective governments may also play an active role and take the lead in attempting to facilitate a conducive setting for sustainable VC funds. This may be done in three key ways: (1) crafting an autochthonous and workable definition of sustainable finance in line with what governments are able to provide; (2) enacting effective policies to expand the source of funding and diversify the types of investors available; and (3) exploring and getting involved with PPP projects which could collaborate with sustainable VC funds.

First, governments may attempt to develop a clear definition and a set of targeted regulations or legislation concerning relevant matters such as qualifications as sustainable company and sustainability information disclosure. In this respect, this paper does not attempt to instruct how governments should do so, but merely recommends that this is what governments could do to facilitate fund raising for sustainable VC funds. This is because it would be impractical to provide suggestions as to how a government should compile this definition since each government would necessarily have to incorporate its own domestic considerations (which differ amongst countries with varying needs) in order to formulate a definition of sustainability suitable for its own country. However, as evidenced by efforts made by the EU, it is possible for such a definition to be formulated despite the fact that this appears to be an insurmountable task.

On this score, the EU provides a role model through the clear and detailed EU Taxonomy Regulation accompanied by its surrounding regulations ${ }^{104}$ and has even promised to issue a 'social sustainable investment' definition in the near future. Presently, the EU Taxonomy Regulation not only provides a clear definition of 'environmentally sustainable investment ${ }^{105}$ but also requires that an environmentally sustainable investment must substantially contribute towards one of the six environmental objectives, ${ }^{106}$ and goes on to articulate the types of activities that fall under each of the six objectives. ${ }^{107}$ For instance, if an economic activity claims to substantially contribute towards climate change mitigation, it must be able to prove that its activities are aligned with the long-term temperature goal

\footnotetext{
101 Ahmad et al. (2018), p 40.

102 Lerner and Nanda (2020), p 253.

103 Ibid., pp 253-255.

104 EU Sustainable Investment Taxonomy Regulation, supra n. 16.

105 Ibid.

106 Ibid., Article 9: Environmental objectives.

107 Ibid., Articles 10-15.
} 
of the Paris Agreement and fall under one of the pre-defined categories, including but not limited to renewable energy, energy efficiency, and clean mobility. ${ }^{108}$ It is also observed that various other jurisdictions have also embarked on developing their own domestic sustainable taxonomy. Some examples include Canada, Kazakhstan and Indonesia. ${ }^{109}$ While this remains a long way from the desired goal of international standards and certainty, it is admittedly a much welcomed improvement on the status quo.

Such definitions would also go some way in bringing about much needed clarity for sustainable VC funds. It also eliminates the possibility of funds abusing the 'sustainability' label when it is actually not sustainable at all. This form of abuse manifests itself most through the phenomenon of greenwashing, which lately has been an issue of concern. ${ }^{110}$ Having a definition of what is sustainable investment would minimise the possibility of such abuse and would be useful in addressing the uncertainty which has hindered fund raising for a considerable period of time.

Second, it is also recommended that governments facilitate the raising of capital for sustainable VC funds. There are a number of ways governments can do so. For instance, through policies and changes in regulations, government efforts may help to expand the sources of funds and diversify the types of investors that invest in sustainable VC funds.

Presently, certain local regulatory restrictions may hinder domestic investors from investing in sustainable VC funds. As such, sustainable VC funds end up being suffocated by a 'natural source of long-term local capital'. ${ }^{111}$ Some developing countries also remain beset by insular regulatory frameworks and investment guidelines that could pose further obstacles to domestic investors investing in such sustainable VC funds as are typically based offshore. ${ }^{112}$ This may even be more true if sustainable VC funds have a focus on the country which itself imposes such restrictions. For instance, this was previously the case in China, where certain institutional investors faced prohibitions which straitjacketed their ability to make such equity investments. Policy constraints and applicable quotas imposed by regulations were obstacles that restricted VC investment by institutional investors. ${ }^{113}$ This meant that VC as an effective vehicle in promoting sustainable investing would be unduly inhibited. However, the restrictive effect of this policy was recognised and regulators have, since 2008 , been taking the necessary actions to correct this, thereby promoting long-term investments in VCs by institutional investors and foreign investors. On this score, special attention should be paid to the relaxation of restrictions placed on institutional investors raising VC funds, including sustainable VC funds.

Third, governments could explore more channels of public-private collaboration in the sustainable VC space. The PPP structure explored in Section 3 is one such example. In addition, governments could consider business incubators collaboratively set up by government agencies and sustainable VC funds. ${ }^{114}$ Such business

\footnotetext{
108 Ibid., Article 10: Substantial contribution to climate change mitigation.

109 OECD (2020), 2.4.

110 O'Mahony and Awan (2021).

111 Ahmad et al. (2018), p 40.

112 Ahmad et al. (2018).

113 Lin (2017), p 173.

114 Baker (2014).
} 
incubators help sustainable VC funds to add more value to portfolio companies through expertise and connections in the public and private sectors. Governments could also intentionally cultivate a greater talent pool in sustainable investing by updating curricula for higher education. This idea was also mooted by Lerner, albeit conservative in noting that such collaboration may not necessarily guarantee success unless it is 'executed correctly'. In particular, the example of FONDCE mentioned above was inspired by Israel's Yozma Fund. While this is an impact fund, the lessons it provides would similarly be applicable to sustainable funds. The Yozma Fund utilises a modified waterfall structure and meets the appropriate 'golden mean' to incentivise private capital in tandem with public capital. ${ }^{115}$ This requires an appropriate public to private capital ratio which does not prohibitively inhibit fund raising. The simple fact that the Yozma Fund is an impact fund does not detract from the plausible chances of such an approach facilitating fund raising by sustainable VC funds. The lessons learnt should be considered seriously by governments in efforts to create a more facilitative environment for raising capital.

In conclusion, considered from an entity approach, there are two main players that could do more to advance the fund-raising process: VC funds, which could adapt traditional and sometimes rigid practices through contractual mechanisms to better suit the sustainable sector; and governments, which could play a more active role in facilitating a fund-raising environment. Lastly, it is also worth noting that a tangential method whereby governments may further improve funding for $\mathrm{VC}$ funds is to adopt a broader approach rather than being myopic and focusing solely on funds alone. For the sake of completeness, it is worth mentioning that governments should also consider facilitating the development of potential portfolio companies through accelerators. ${ }^{116}$ This would serve to minimise risk or uncertainty that investors may perceive on the part of potential portfolio companies, which would hopefully reassure them and facilitate the fund-raising process.

\subsection{Investment Stage}

The biggest challenge for sustainable VC fund managers in constructing a successful sustainable portfolio concerns their ability to identify portfolio companies and entrepreneurs that can faithfully adhere to the sustainable goals and at the same time generate a positive profit.

In this respect, this paper submits that sustainable $\mathrm{VC}$ funds could take full advantage of their stronghold in corporate governance rights to promote the sustainability of its portfolio companies. Corporate engagement and shareholder activism have been identified as key strategies of sustainable investment, whereby the fund makes use of its shareholder power to gear portfolio companies towards making sustainable corporate decisions. ${ }^{117}$ Sustainable VC funds are particularly well positioned to make use of corporate engagement and governance mechanisms compared

\footnotetext{
115 Lerner (2012).

116 Ahmad et al. (2018), p 28.

117 Global Sustainable Investment Alliance (2019), p 7.
} 
to other forms of financing. It has been well noted that VC funds tend to assume greater de facto influence than the voting rights associated with their equity stake in the portfolio companies. ${ }^{118}$ Such control takes the form of board representation, veto rights and informal influence over corporate decisions. ${ }^{119}$

Staged financing also provides greater control to sustainable VC funds as subsequent rounds of financing will not materialise if key business objectives are not met. Such objectives can be set with a sustainable focus to ensure that portfolio companies deliver on their sustainable promises. Staged financing, together with the reputational mechanism in the $\mathrm{VC}$ community, acts as a strong vanguard against greenwashing and poor quality of sustainability information disclosure. If the existing investors choose to step out from start-ups in subsequent rounds of financing, the reputational mechanism works in such a way as to preclude alternative investors as they are warned of potential loopholes and non-trustworthiness in these particular start-ups. Furthermore, the continuous monitoring conducted by VC fund managers $^{120}$ means that they are more familiar with the actual operations of the start-ups and whether they indeed deliver on their sustainable promises. Sustainable start-ups who truly want to make a success of their business would therefore be incentivised to keep working hard and stay truthful, preventing a market for lemons.

On this note, it is valuable to observe how the content of investors' fiduciary duties has shifted in recent years to include an obligation to incorporate ESG considerations alongside financial returns. An important illustration is the modern fiduciary duty introduced by the Final UNEP Report issued by the PRI and UNEP FI in 2019. ${ }^{121}$ The Final UNEP Report justifies the modern fiduciary duty through three key limbs: first, ESG incorporation is now an investment norm; second, ESG issues are financially material; and lastly, policy and regulatory frameworks are changing to require ESG incorporation. As identified and labelled by MacNeil and Esser, ${ }^{22}$ this is the financial 'intermediary' fiduciary duty operating within the investment chain which has evolved from a 'permissive' model where one may incorporate ESG considerations, to the 'mandatory' model where one has to incorporate ESG considerations into the investment process.

Such a shift in the content of fiduciary duty is valuable for the growth of sustainable VC funds as it encourages and justifies fund managers' incorporation of ESG considerations in their portfolio selection. This paves the way for more generic VC funds to opt for a sustainable focus. Moreover, the Final UNEP Report is comprehensive enough to acknowledge the differences between jurisdictions where 'obligations equivalent to "fiduciary duties" manifest themselves as "statutory provisions' in civil law jurisdictions despite their common law roots. It identifies 'common themes' amongst the various civil law jurisdictions and concludes that fiduciary duties in both common and civil law jurisdictions exist such that ESG considerations are included.

Overall, the investment stage is where sustainable VC funds should make full use of their edge in terms of tailored contractual designs, greater corporate governance rights and continuous monitoring to make sure that start-ups achieve their

\footnotetext{
118 Gilson (2003), pp 1081-1083.

119 Lin (2021), pp 1-43.

120 Gilson (2003), p 1072.

121 Sullivan et al. (2019).

122 MacNeil and Esser (2021).
} 
sustainable goals. This stage makes VC particularly valuable for sustainable investing, since it offers special vantage points to tackle the heightened uncertainty and information asymmetry present in the emerging sustainable investing market.

\subsection{Exit Stage}

VC investments exit at a time when the fund managers are confident that the startups have achieved a certain level of maturity, with increased value, ability to attract further rounds of financing through IPOs, M\&As or other means, and a firm business structure to contribute towards sustainable economic activities. Accordingly, at the exit stage, the main issue pertains to the lack of suitable exit mechanisms for sustainable VC funds. A wide range of exit options available to VCs remain important as they ensure that VCs are able to realise the fruits of their investments. As astutely pointed out by the IFC, respondents in the GIIN's Annual Impact Investor Survey 2018 reflected that the lack of suitable exit options remained 'a challenge in the impact investment industry'. ${ }^{123}$ In this regard, structural reforms in terms of institutional design may be necessary to support viable exits and eventual realisation of returns on investment in the following ways.

First, following the same logic of a specialised technology and innovation board to be set up by stock exchanges around the world, ${ }^{124}$ it is suggested that a specialised stock market board be created for companies that focus on sustainability or have a strong sustainability practice (a 'sustainability board'). The idea of separating stocks with strong sustainability performance from their peers is a familiar concept in the market. Secondary boards with a focus on innovation or technology include the Shanghai Stock Exchange's STAR Market, or even the Hong Kong Exchange's Sustainable and Green Exchange (STAGE). ${ }^{125}$ Beyond just establishing a specialised sustainability board, regulators may consider reforming or introducing more flexible rules to facilitate exits by green sustainable funds and start-ups. These rules can apply either to the main boards, but also to the said specialised secondary boards. ${ }^{126}$

In contrast to the complexity of listing requirements for the main board, companies to be listed on a sustainability board should enjoy the same benefits and conveniences as start-ups on technology and innovation boards. This approach would mean that the securities regulator and the stock exchange themselves pay less attention to the documentation submitted in the IPO process, but rely more on checks and verifications carried out by the underwriters or sponsors of the issuer. An example of this expedited process can be seen in China's reform from the existing time-consuming

\footnotetext{
123 Ahmad et al. (2018), p 39.

124 Examples of technology and innovation boards include the NASDAQ in the U.S., the Science and Technology Innovation Board at the Shanghai Stock Exchange in China, the Growth Enterprise Market at the Hong Kong Stock Exchange and the Catalist Board at the Singapore Stock Exchange.

125 Lin (2021), pp 213-304.

126 Ibid., p 235.
} 
approval-based IPO regime to a registration-based IPO regime. ${ }^{127}$ Stringent listing requirements such as the profitability requirement and the cash-flow requirement should also be lowered for companies and especially start-ups with a strong sustainable impact. ${ }^{128}$

In exchange for expedience and efficiency offered to IPO on the sustainability board, greater attention should be paid to the importance of ongoing disclosure obligations, ${ }^{129}$ as well as to investor education in terms of cultivating a 'buyer beware' mentality. Overall, the introduction of a specialised sustainability board would make clear the exit venue for sustainable VC investments and therefore boost investor confidence in sustainable investing.

Second, the standardisation and comparability of sustainability information should be enhanced to make the sustainability board more credible and attractive for investors so that VC exits can be made in a more viable way. As it currently stands, sustainability information disclosures made by listed companies themselves suffer from incompleteness, inconsistency and incompatibility. ${ }^{130}$ A report published by the U.S. Government Accountability Office in July 2020 concluded that because companies often use self-devised, varying and divergent methods and criteria in disclosing their sustainable impact, investors found it extremely hard to make comparisons over time and across companies. ${ }^{131}$ This problem is exacerbated when companies make overly generic disclosures, disclose only the measures but not the results, or selectively disclose sections of their business with a more positive ESG outlook. ${ }^{132}$ Such observations are generally applicable to major markets such as China. ${ }^{133}$

In this regard, the EU is taking the lead with a detailed set of regulations concerning the classification of ESG disclosures and disclosure obligations introduced under the EU Taxonomy Regulation and the EU Regulation on Sustainability-related Disclosures. ${ }^{134}$ In tightening the standard of sustainability information disclosure, legislators could borrow salient ideas from established standards of professional organisations. For instance, the SASB framework devised by the Sustainability Accounting Standards Board, a non-profit organisation, provides sector-specific standards and guidance for ESG disclosure in 77 different industries. ${ }^{135}$ These ESG issues are carefully selected by the SASB based on the materiality of their impact on the financial performance of companies. ${ }^{136}$ Another viable framework can be found

\footnotetext{
127 Ibid., pp 234-239.

128 Ibid., at pp 222-230, for an example of how the stringent listing requirements are relaxed for technology and innovation companies seeking an IPO on the STAR board.

129 See explanation below.

130 Palmer et al. (2020).

131 Government Accountability Office, U.S.A. (2020), pp 32-33. Note that while this report focuses on public companies, it is safe to assume that these issues are even more serious with private start-up companies that are less heavily regulated in terms of disclosure obligations.

132 Ibid., at pp 17-31.

133 Pirovska et al. (2019).

134 EU Sustainable Investment Taxonomy Regulation, supra note 16; European Union, Regulation (EU) 2019/2088 of the European Parliament and of the Council of 27 November 2019 on sustainability-related disclosures in the financial services sector.

135 Sustainability Accounting Standards Board (2021a).

136 Sustainability Accounting Standards Board (2021b).
} 
in the Recommendations of the Task Force on Climate-related Financial Disclosures (TCFD). ${ }^{137}$ The TCFD standard differs from the SASB standard in the sense that it only concerns climate-related topics and provides both general and sector-specific guidance. Noticeably, the TCFD framework has already been incorporated by the EU, the UK and Hong Kong in their mandatory ESG disclosure regimes. ${ }^{138}$ Hence, specialist second tier boards should adopt, for the sake of clarity, a standard set of sustainable disclosure measures instead of leaving companies to choose.

Meanwhile, the appropriate use of technology such as machine learning and artificial intelligence in data collection and processing could significantly improve the capacity and efficiency of sustainability impact measurement. ${ }^{139}$ The Spatial Finance Initiative is one example of the application of state-of-the-art technology in measuring sustainability risks and impacts. ${ }^{140}$ This Initiative focuses on the integration of geospatial data (including but not limited to Earth Observation Data from the National Aeronautics and Space Administration (NASA), remote sensing, payment systems, and telecommunications) with financial theories and practice to develop applications related to climate risk, ESG transparency and verification. ${ }^{141}$ Technological processes of this kind are greatly beneficial for the purpose of cross-checking and verifying the sustainability impact of companies.

It is crucial for government policies to promote the growth of third-party sustainability rating agencies to boost investors' confidence in investing in sustainable business on the secondary market. Current examples of such agencies include the ESG Evaluation Framework Developed by S\&P Global Ratings ${ }^{142}$ and the ESG Relevance Scores developed by Fitch Ratings. ${ }^{143}$ However, it should be cautioned that, as the number of such rating agencies is growing, government agencies should also intervene at the appropriate timings to make sure that there is some form of standardisation of the impact assessment criteria used by these agencies, lest investors will again be confronted by a plethora of varying standards. In developing a common set of impact assessment standards, governments could borrow from existing matrices developed by credible international organisations. For instance, the World Economic Forum has released a set of 21 sustainability matrices for ESG impact assessment. $^{144}$ The Organisation for Economic Co-operation and Development (OECD) has also developed a set of 'well-being metrics' that measure a company's impact on current and future well-being and sustainability. ${ }^{145}$ In implementing a

\footnotetext{
137 Task Force on Climate-related Financial Disclosures (2017).

138 Clarkin et al. (2020).

139 Avgouleas (2021), pp 18-22.

140 Spatial Finance Initiative (undated a \& b).

141 Avgouleas (2021).

142 S\&P Global Ratings (2020). This ESG Evaluation Framework is 'a cross-sector, relative analysis of an entity's capacity to operate successfully in the future and is grounded in how ESG factors could affect stakeholders, potentially leading to a material direct or indirect financial impact on the entity'.

143 Irving and Dwyer (2020). The ESG Relevance Scores present the relevance and materiality of ESG risks with respect to the rating decision.

144 World Economic Forum (2020).

145 OECD (2018), chapter 9.
} 
common set of standards, the government could make the incorporation or adoption of such standards, in full or in part, by the rating agencies a pre-requisite for issuing their licence.

While promoting the development of such sustainability credit-rating agencies, governments should be prepared to come up with a set of holistic regulations concerning such groups ab initio. Such regulations should be particularly concerned with the issue of conflict of interest that plagued the credit-rating industry in the 2007-2008 financial crisis. ${ }^{146}$ Since credit-rating agencies have an interest in maintaining a healthy commercial relationship with the companies paying them to conduct credit ratings, they may be incentivised to inflate or glorify the ratings. In fact, there have already been news reports of rating agencies colluding with pollutive companies to issue fraudulent sustainability reports. ${ }^{147}$ On this aspect, regulatory mechanisms should be designed to encompass ex-ante qualification and licensing, ongoing monitoring and supervision, and ex-post punishment for abuse of such agencies. $^{148}$

Third, compatible with the suggestion of creating a sustainability-focused stock market is the idea of constructing an eco-system for sustainable investing. Such an eco-system would include the three key players in the VC cycle, namely investors who provide funding, fund managers who select and add value to the portfolio companies, and portfolio companies that operate a sustainable business, and form a closed loop for the flow of capital. ${ }^{149}$ Figure 5 below sets out a possible conception of the sustainable VC cycle from fund raising to exit. Capital enters the eco-system through investments made by investors, and is then invested in sustainable projects handpicked by the VC fund managers.

The value of the capital increases with appropriate management by the VC fund managers and advice from commercial and industrial experts who often value-add to the portfolio companies. The investment eventually realises its returns via exit strategies such as IPOs or M\&As, and can be subsequently channelled back into the eco-system for another round of financing.

It can be observed from Figure 5 that sustainability education and the cultivation of sustainability awareness is crucial in every step of the cycle. Investors with the intention to finance sustainable companies are more likely to seek out sustainable VC funds. ${ }^{150}$ Sustainable VC funds can only construct a successful portfolio if there is a sufficient number of environmentally conscious entrepreneurs who faithfully operate their businesses in ways that contribute towards a sustainable future. There is also a need for a group of specialists with the requisite knowledge of the industry in which specific portfolio companies operate and of how sustainability can

\footnotetext{
$\overline{146}$ Efing and Hau (2015), pp 46-60.

147 Zhen (2019).

148 See, for example, International Organization of Securities Commissions (2017), Section F: Principles for Auditors, Credit Rating Agencies, and other Information Providers, Principle 22.

149 Salzmann (2013), pp 568-572.

150 Newburger (2020).
} 


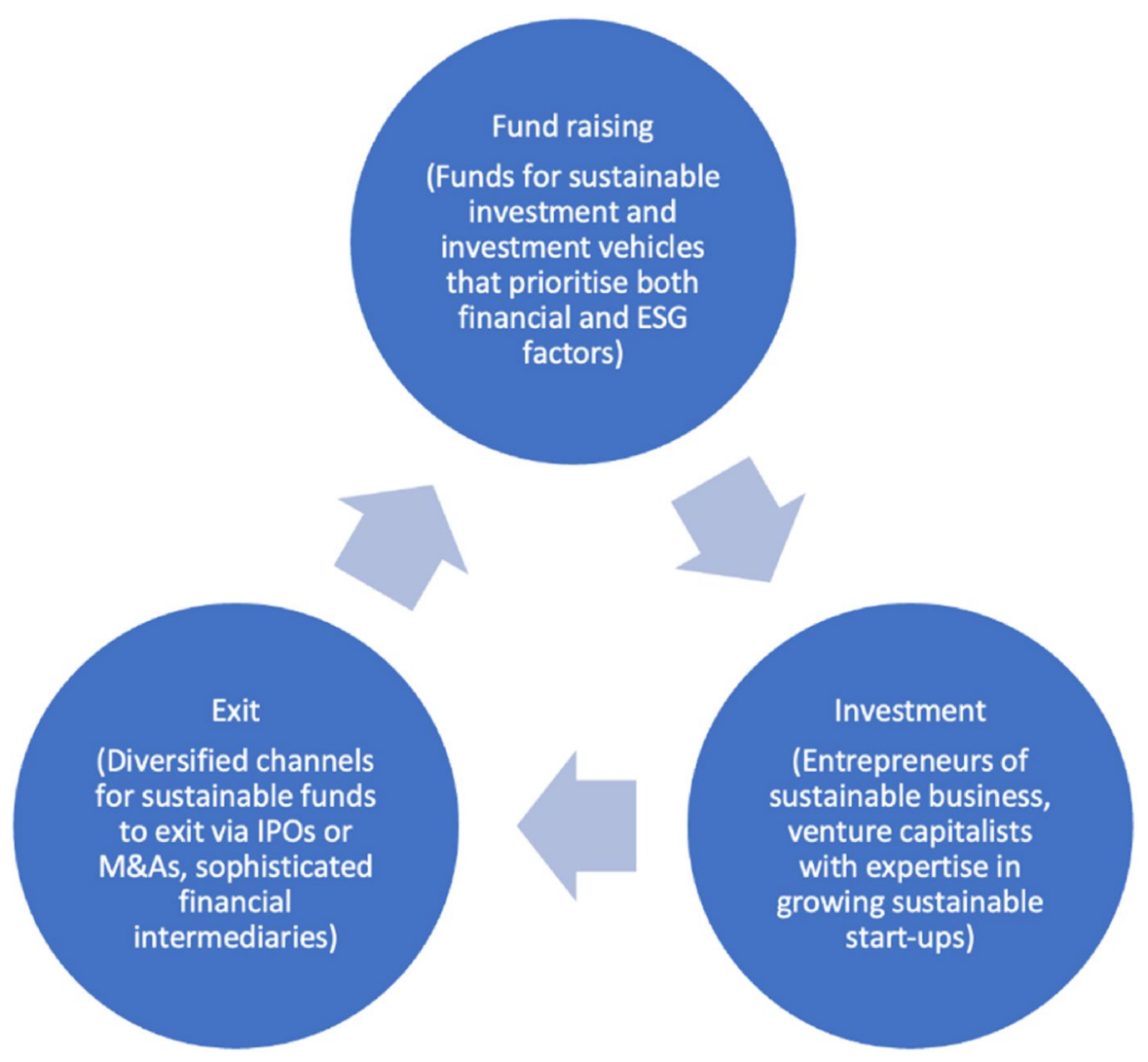

Fig. 5 The cycle of sustainable VC investing

be incorporated into their business operations. ${ }^{151}$ Finally, a greater chance of a successful exit of a sustainable portfolio company can only be guaranteed if the market in general embraces such an idea. Such a positive market environment requires a greater willingness and proactivity of mega-corporations to acquire sustainable start-ups through M\&As, ${ }^{152}$ and of stock market investors to actively purchase stock in listed companies with a strong record of sustainability. A well-designed sustainability education policy can be a rising tide that lifts up the entire eco-system for sustainable VC investment. The regulatory bodies can play an instrumental role in facilitating the link between fund raisers and green project investors.

As such, it is crucial for the government to design a sustainability education programme that reaches out to every potential stakeholder in the eco-system. This programme could encompass public policy communications on the mass media targeted at the public, revamped university curricula targeted at fresh graduates entering the work force, and professional training sessions targeted at professionals and experts.

\footnotetext{
151 Weinreb (2018).

152 Rajeev (2019).
} 
One essential aspect of sustainability education is investor education, where investors should be informed of the urgency and importance of sustainability matters on the one hand, and be equipped with the necessary knowledge to appropriate the right type of sustainable investment for themselves on the other. ${ }^{153}$ Doing so should also reduce the currently prevalent sentiment of apprehension among investors with regard to sustainable investing. ${ }^{154}$ While VC investment is mostly open to institutional investors and not retail investors, greater interest by retail investors (e.g., in buying stocks of sustainable listed companies) is still beneficial for the sustainable VC industry by making exit options more viable. Overall, with the help of a carefully designed sustainability education programme, the sustainable VC eco-system stands to evolve in terms of maturity, self-sufficiency and vibrancy.

\section{Conclusion}

In conclusion, the immense inflow of capital into sustainable investment is a phenomenon that should be welcomed. To this end, VCs are also well poised to take advantage of and further buttress its continued growth. However, more could possibly be done to ensure that VCs do so. Hence, this precipitates a dualist strategy encompassing a contractarian approach with government support. Ultimately, it is hoped that the recommendations proposed in this paper will help to develop the sector and craft a stronger role for VCs in the field of sustainable investing.

Acknowledgements I thank the interviewees who have generously shared their knowledge and insights with me. I am grateful to Mr Bai Bo and Ms Liao Jia from the Asian Green Fund and Mr Li Ting from the ECO Fund. I thank Iris Chiu, Dirk Zetzsche, Xia Mian and Chan You Quan for their valuable comments on earlier drafts of this paper. The research is supported by the Centre for Banking and Finance Law of the National University of Singapore. All errors remain my own.

\section{References}

Ahmad RA, Reed L, Zhang R (2018) Private equity and venture capital's role in catalysing sustainable investment. International Finance Corporation, World Bank Group

An G (2017) Broad prospect of green fund development in China. Financ Market 8:72-74

An G et al. (2018) 国内外绿色基金发展㸴究 [Studies on the development of domestic and foreign green funds]. China Finance Publications, Beijing

Asia Green Fund (undated) http://www.asiagreenfund.com/html/en_portfolio/. Accessed 13 May 2021

Avgouleas E (2021) Resolving the sustainable finance conundrum: activist policies and financial technology. Law Contemp Probl 84:15-18

AXA Investment Managers (2021) Responsible investing. https://www.axa-im.com.sg/responsibleinvesting. Accessed 13 May 2021

Baker B (2014) ' 5 incubators that are shaping the future of green business'. EcoWatch. https://www. ecowatch.com/5-incubators-that-are-shaping-the-future-of-green-business-1881859789.html. Accessed 28 Jan 2021

\footnotetext{
153 von Daeniken (2020).

154 Standard Chartered PLC (2020), p 10.
} 
Beijing Daily (2017) 百亿低碳基金落户雄安 助推碳市场流动性增强 ['Low-carbon fund worth ten billion RMB settled in Xiong' an to boost carbon market liquidity']. Xinhua News, 11 Nov 2017. http://www.xinhuanet.com/fortune/2017-11/11/c_129738204.htm. Accessed 6 Jan 2021

Berrou R, Dessertine P, Migliorelli M (2019) An overview of green finance. In: Migliorelli M, Dessertine P (eds) The rise of green finance in Europe: opportunities and challenges for issuers, investors and marketplaces. Palgrave Macmillan, Switzerland

Bioy H, Stuart E, Boyadzhiev D (2019) European sustainable funds landscape. Morningstar, Chicago

BlackRock (undated a) Sustainable Investing. https://www.blackrock.com/us/individual/investmentideas/sustainable-investing. Accessed 6 Jan 2021

BlackRock (undated b) Sustainable Investment Solutions. https://www.blackrock.com/us/individual/ investment-ideas/sustainable-investing/sustainable-solution. Accessed 6 Jan 2021

BlackRock (undated c) ESG Integration. https://www.blackrock.com/us/individual/investment-ideas/ sustainable-investing/esg-integration. Accessed 6 Jan 2021

Bocken NMP (2015) Sustainable venture capital—catalyst for sustainable start-up success? J Clean Prod 108:647-658. https://doi.org/10.1016/j.jclepro.2015.05.079

Breen S, Campbell C (2017) Legal considerations for a skyrocketing green bond market. Nat Resour Environ 31:16-20

Bureau of Energy Efficiency, India (undated a) VCFEE-Achievements. https://beeindia.gov.in/content/ vcfee-acheivements. Accessed 6 Jan 2021

Bureau of Energy Efficiency, India (undated b) Venture Capital Fund for Energy Efficiency. https:// beeindia.gov.in/content/vcfee-acheivements. Accessed 6 Jan 2021

China PPP Fund (2016) 关于我们 [About us]. http://www.cpppf.org/investment/index.html. Accessed 6 Jan 2021

China Public Private Partnership Centre (2020) China PPP Fund drives forward the guided, healthy and sustainable PPP development. http://www.cpppc.org/en/szyw/999262.jhtml. Accessed 6 Jan 2021

China Social Investment Forum (2019) 中国责任投资年度报告 2019 [China Sustainable Investment Review 2019]. http://www.syntaogf.com/Uploads/files/\%E4\%B8\%AD\%E5\%9B\%BD\%E8\%B4\% A3\% $4 \%$ BB\%BB\%E6\%8A\%95\%E8\%B5\%84\%E5\%B9\%B4\%E5\%BA\%A6\%E6\%8A\%A5\%E5\% 91\%8A2019.pdf. Accessed 31 Nov 2021

China-U.S. Green Fund (undated) 基金投资理念与策略 [Investment model and strategies]. http://www. china-usgreenfund.com/p/touziguanli.html. Accessed 6 Jan 2021

Christie AL (2021) The agency costs of sustainable capitalism. University of Cambridge Faculty of Law Legal Studies Research Paper No. 7/2021. https://papers.ssrn.com/sol3/papers.cfm?abstract_id= 3766478

Clarkin C, Levin J, Sawyer M (2020) The rise of standardized ESG disclosure frameworks in the United States. The Harvard Law School Forum on Corporate Governance. https://corpgov.law.harvard.edu/ 2020/06/22/the-rise-of-standardized-esg-disclosure-frameworks-in-the-united-states/. Accessed 28 Jan 2021

Cumming D, Johan S, MacIntosh JG (2017) A drop in an empty pond: Canadian public policy towards venture capital. Econ Polit Ind 44:103-117. https://doi.org/10.1007/s40812-016-0063-4

DBL Partners (undated) We are venture capitalists and impact investors. http://www.dblpartners.vc. Accessed 6 Jan 2021

Different Funds (2020) The rise of ESG in venture capital. https://differentfunds.com/esg/rise-of-esgventure-capital. Accessed 6 Jan 2021

EcoSummit (undated) About. https://ecosummit.net/about. Accessed 6 Jan 2021

Efing M, Hau H (2015) Structure debt ratings: evidence on conflicts of interest. J Financ Econ 116:46-60

Energy for Environment Foundation (2021) ESCO Revolving Fund. http://www.efe.or.th/escofund.php? task $=8$. Accessed 6 Jan 2021

ETF Partners (undated) The Environmental Technologies Fund. https://etfpartners.capital/. Accessed 6 Jan 2021

European Investment Fund (2021) EIF for venture capital \& private equity funds : how to submit an investment proposal. https://www.eif.org/EIF_for/venture_capital_equity_funds/index.htm. Accessed 22 Jun 2021

Fidelity International (2021) Understanding ESG investing. https://www.fidelity.com.sg/beginners/esginvesting. Accessed 21 May 2021

Four Rivers Investment (undated) 公司介绍 [About us]. https://www.fourriversinvestment.com/gongs ijieshao.html. Accessed 6 Jan 2021 
GEEREF (undated a) What GEEREF does. https://geeref.com/about/what-geeref-does.html. Accessed 6 Jan 2021

GEEREF (undated b) What GEEREF is. https://geeref.com/about/what-geeref-is.htm. Accessed 6 Jan 2021

GEEREF (undated c) Portfolio. https://geeref.com/portfolio.html. Accessed 6 Jan 2021

Gilson R (2003) Engineering a venture capital market: lessons from the American experience. Stanf Law Rev 55:1067-1103

Global Impact Investing Network (2021) What you need to know about impact investing. https://thegiin. org/impact-investing/need-to-know/. Accessed 13 May 2021

Global Sustainable Investment Alliance (2013) 2012 Global Sustainable Investment Review. http://gsiar eview2012.gsi-alliance.org/pubData/source/Global\%20Sustainable\%20Investement\%20Alliance. pdf. Accessed 11 Dec 2021

Global Sustainable Investment Alliance (2015) 2014 Global Sustainable Investment Review. http://www. gsi-alliance.org/wp-content/uploads/2015/02/GSIA_Review_download.pdf. Accessed 11 Dec 2021

Global Sustainable Investment Alliance (2017) 2016 Global Sustainable Investment Review. http://www. gsi-alliance.org/wp-content/uploads/2017/03/GSIR_Review2016.F.pdf. Accessed 11 Dec 2021

Global Sustainable Investment Alliance (2019) 2018 Global Sustainable Investment Review. http://www. gsi-alliance.org/wp-content/uploads/2019/03/GSIR_Review2018.3.28.pdf. Accessed 31 Dec 2021

Global Sustainable Investment Alliance (2021) Global Sustainable Investment Review 2020. http://www. gsi-alliance.org/wp-content/uploads/2021/08/GSIR-20201.pdf. Accessed 11 Dec 2021

Government Accountability Office, U.S.A. (2020) Public companies disclosure of environmental, social and governance factors and options to enhance them (July 2020)

Green Startups (undated) 什么是绿叶投资? [What is Green Leaves Investment?]. http://www.greenstartups. cn/about-us/green-leaf-fund/. Accessed 6 Jan 2021

Hale J (2020) Sustainable funds U.S. Landscape Report—record flows and strong fund performance in 2019. Morningstar, Chicago

International Organization of Securities Commissions (2017) Objectives and principles of securities regulation. https://www.iosco.org/library/pubdocs/pdf/IOSCOPD561.pdf. Accessed 31 Nov 2021

Irving S, Dwyer M (2020) What investors want to know: ESG relevance scores for corporates. Fitch Ratings. https://www.fitchratings.com/research/corporate-finance/what-investors-want-to-know-esg-relevancescores-for-corporates-20-02-2020. Accessed 28 Jan 2021

Krämer-Eis H, Pelly R (2011) Creating a better business environment for financing business, innovation and green growth. OECD J Financ Market Trends 2011:129-140. https://doi.org/10.1787/fmt-2011-5kg55 qw0x $7 x x$

Lerner J (2012) Boulevard of Broken Dreams: why public efforts to boost entrepreneurship and venture capital have failed - and what to do about it. California Princeton Fulfillment Services

Lerner J, Nanda R (2020) Venture capital's role in financing innovation: what we know and how much we still need to learn. J Econ Perspect 34:237-261. https://doi.org/10.1257/jep.34.3.237

Lin L (2017) Engineering a venture capital market: lessons from China. Columbia J Asian Law 30:160-220

Lin L (2021) Venture capital law in China, 1st edn. Cambridge University Press

Lin L (2019) Private equity in Singapore: In: Booysen S et al. (eds) Financial services law and regulation. SAL, Singapore

Lu W (2018) 发改委官员加盟中美绿色基金:如何绿动中国发展? [Officials from the National Development and Reform Commission joined the China-US Green Fund: how to push for China's green development?]. Sina, 3 Nov 2018. https://finance.sina.com.cn/chanjing/gsnews/2018-11-05/doc-ihmutuea65 31209.shtml. Accessed 6 Jan 2021

MacNeil I, Esser I-M (2021) From a financial to an entity model of ESG. Social Science Research Network, Rochester

Nassiry D, Wheeler D (2011) A green venture fund to finance clean technology for developing countries. Center for Global Development

Newburger E (2020) Amid climate crisis, investors are starting to put their money towards a sustainable future. CNBC, 25 Jan 2020. https://www.cnbc.com/2020/01/24/climate-crisis-investors-putting-moneytowards-sustainable-future.html. Accessed 28 Jan 2021

OECD (2018) For good measure: advancing research on well-being metrics beyond GDP

OECD (2020) Developing sustainable finance definitions and taxonomies

O'Mahony D, Awan M (2021) ESG: greenwashing and the EU Taxonomy Regulation-Part 1-Greenwashing, what is it? https://www.matheson.com/insights/detail/greenwashing-and-the-eu-taxonomy-regul ation-part-one. Accessed 6 Jun 2021 
Palmer H, Gregory H, Wood L (2020) Emerging ESG disclosure trends highlighted in GAO Report. The Harvard Law School Forum on Corporate Governance. https://corpgov.law.harvard.edu/2020/08/15/ emerging-esg-disclosure-trends-highlighted-in-gao-report/. Accessed 28 Jan 2021

People's Bank of China et al. (2016) 中国人民银行、财政部、发展改革委等关于构建绿色金融体系的 指导意见 [Guiding Opinions of the People's Bank of China, the Ministry of Finance, the National Development and Reform Commission, and other Departments on building a green financial system]

Pirovska M et al. (2019) ESG data in China-recommendations for primary ESG indicators. UN Principles for Responsible Investment. https://www.unpri.org/download?ac=6500. Accessed 31 Nov 2021

Punzi MT (2018) Role of bank lending in financing green projects: a dynamic stochastic general equilibrium approach. Asian Development Bank Institute (ADBI), Tokyo

Rajeev P (2019) Can start-ups help big business become sustainable? Eco-Business. https://www.eco-busin ess.com/news/can-start-ups-help-big-business-become-sustainable/. Accessed 28 Jan 2021

S\&P Global Ratings (2020) ESG evaluation-sustainable practices. Sustainable returns. https://www.spglo bal.com/ratings/en/research/pdf-articles/190401-esg-evaluation-brochure. Accessed 31 Nov 2021

Salzmann AJ (2013) The integration of sustainability into the theory and practice of finance: an overview of the state of the art and outline of future developments. J Bus Econ 83:555-576

SET Ventures (undated) Investing in the energy system transition. https://www.setventures.com. Accessed 6 Jan 2021

Sina Finance (2020) 三峡资本发起设立三峡绿色产业 (山东) 基金 [China Three Gorges Corporation initiated and set up the Three Gorges Green Industry (Shandong) Fund], 16 May 2020. https://finance. sina.com.cn/enterprise/central/2020-05-16/doc-iirczymk1916982.shtml. Accessed 6 Jan 2021

Social Impact Capital (undated) Social impact + venture capital = social impact capital. https://socialimpact-capital.com/. Accessed 6 Jan 2021

Sohu (2020) 绿动资本白波:技术赋能绿色影响力投资,创造可持续资本回报 [Asia Green Fund Baibo: technology empowers green impact investment and creates sustainable capital returns]. https://www. sohu.com/a/414978894_413933. Accessed 6 Jan 2021

Spatial Finance Initiative (undated a) GeoAsset. https://spatialfinanceinitiative.com/geoasset-project/. Accessed 28 Jan 2021

Spatial Finance Initiative (undated b) The initiative. https://spatialfinanceinitiative.com/. Accessed 28 Jan 2021

Standard Chartered PLC (2020) Standard Chartered Sustainable Investing Review 2020_ Growing sustainable investments through knowledge

Sullivan R et al. (2019) Fiduciary duty in the 21st century: final report. UN Principles for Responsible Investment and UNEP Finance Initiative

Sustainability Accounting Standards Board (2021a) Download SASB Standards. https://www.sasb.org/stand ards/download/. Accessed 28 Jan 2021

Sustainability Accounting Standards Board (2021b) Standards overview. https://www.sasb.org/standards/. Accessed 28 Jan 2021

Talbot KM (2017) What does green really mean?: How increased transparency and standardization can grow the green bond market. Villanova Environ Law J 28:127-145

Task Force on Climate-related Financial Disclosures (2017) Final report-recommendations of the task force on climate-related financial disclosures

Tsing Capital (undated) About us. http://www.tsingcapital.com/index.php?file=chindex.html. Accessed 6 Jan 2021

UN Principles for Responsible Investment (2021) What are the Principles for Responsible Investment? https://www.unpri.org/pri/what-are-the-principles-for-responsible-investment. Accessed 21 May 2021

von Daeniken D (2020) Sustainability: investor education can lead to long-term, resilient growth. Emerging Market Views, 28 Oct 2020. https://em-views.com/sustainability-investor-education-can-lead-to-longterm-resilient-growth. Accessed 28 Jan 2021

Wang EK (2018) Financing green: reforming green bond regulation in the United States. Brooklyn J Corp Financ Commer Law 12:467-491

Weinreb E (2018) Sustainability careers of the future require depth and breadth. https:/www.greenbiz.com/ article/sustainability-careers-future-require-depth-and-breadth. Accessed 28 Jan 2021

World Economic Forum (2020) Measuring stakeholder capitalism: towards common metrics and consistent reporting of sustainable value creation-White Paper. https://www3.weforum.org/docs/WEF_IBC_ Measuring_Stakeholder_Capitalism_Report_2020.pdf. Accessed 31 Nov 2021 
Xinhua News Agency (2017) 国内首只钢铁产业结构调整基金签署框架协议 [Structural agreement signed for the First Domestic Steel Industry Structure Adjustment Fund]. http://www.xinhuanet.com/ fortune/2017-04/07/c_1120770734.htm. Accessed 6 Jan 2021

Zabarenko D, Walter F, Danielsen K (2018) Accelerating public-private partnerships for sustainable development growth. P4G Partnering for Green Growth and the Global Goals 2030, Washington DC

Zetzsche DA (2021) Regulating sustainable finance in the dark. European Business Organization Law Review, this volume

Zhang R, Lu K (2020) 当我们在聊可持续发展金融,我们究竟在聊什么? [What are we really talking about when we speak of sustainable finance?]. CASVI, 16 March 2020. https://www.casvi.org/h-nd905.html. Accessed 31 Nov 2021

Zhen H (2019) 警惕第三方环保服务机构成为污染帮凶 [The police warns third-party sustainability service agencies against colluding with pollutive companies]. http://opinion.people.com.cn/n1/2019/0514/ c1003-31083051.html. Accessed 28 Jan 2021

Publisher's Note Springer Nature remains neutral with regard to jurisdictional claims in published maps and institutional affiliations. 